Conflicting Conceptions of Domestic Space

Shantytowns and State Housing in Contemporary Argentine Cinema

Adriana Laura Massidda

a.massidda@conicet.gov.ar

Saavedra 15, C1083ACA

Buenos Aires

Argentina

+54.9.11.7166.5509 
This article analyses the ways in which two contemporary Argentine films, Villa (Ezio Massa, 2008) and Diagnóstico esperanza (César González, 2013), portray domestic space, to argue that both, in different ways, challenge the state notion of home as a cell of a larger, normalised, social system. Villa, which takes place in the shantytown Villa 21, underlines the dynamism and liveliness of public spaces, and echoes tropes on shantytown residents' solidarity. In contrast, Diagnóstico esperanza takes place in the social housing complex Carlos Gardel and focuses on a verbally violent single-parent household. While both films denounce the marginalisation of the urban poor, Villa ultimately celebrates the qualities of shantytown space, while Diagnóstico esperanza performs a more radical denunciation by shocking the viewer and questioning the idea of a well-functioning society. Thus, both films are revealed to be antithetical to the very notion of 'home' that the state once intended to impose.

$\underline{\text { Keywords }}$

César González, determinism, Diagnóstico esperanza, space, shantytowns, social housing, Villa, Ezio Massa 


\section{Conflicting Conceptions of Domestic Space}

\section{Shantytowns and State Housing in Contemporary Argentine Cinema}

$\underline{\text { Space and society }}$

For more than a century space and the environment have been seen as able to influence human behaviour. Since the nineteenth century theories on social reform, in turn themselves based on spatial determinism, have reflected the conviction that not only geographies but also lived environments, such as urban and domestic spaces, can have an effect on the human mindsets and actions that unfold within them (Ernste and Philo, 2009). Conversely, built environments and inhabited spaces have been also read as the materialisation or the embodiment of social structure and practice.

These approaches had a crucial influence on architectural design, public policy, and more specifically on architectural and policy discussions about social housing. In latenineteenth century Britain, for example, charitable bodies such as the Peabody Trust worked to offer housing to the working classes not only for humanitarian reasons but also in the more general conviction that these would lead to a better society ('The Peabody Trust and the Poor', 1885; Peabody Group, 2017). In Argentina, this tradition of social reform was materialised, amongst others, in urban plans such as Domingo Faustino Sarmiento's programme of parks on the urban fringe of Buenos Aires (itself part of a more general concern for the management of growth and the structuring of the city), and in twentiethcentury discussions on housing (Gorelik, 1998: 35-74). To be sure, the way in which the housing discussion emerged in Argentina was structured by a few different sets of concerns. On the one hand, linked to the tradition of social reform, housing and its relation with social wellbeing had been already contemplated since the start of the century by charitable organisations such as the Sociedad San Vicente de Paul and also by a publicly funded body, 
the Comisión Nacional de Casas Baratas [National Commission of Affordable Houses] (CNCB) (Rigotti, 1991).

Simultaneously, in the context of both a growing need for urban affordable accommodation, and a more general shift in Argentine policies from economic ideas of liberalism to a growing celebration of state intervention in public matters, debates about housing increasingly pointed to the fact that housing provision could not be left to the private market alone (Lecuona, 2001; Ballent, 2005: 55-62). This process culminated with the policies of Juan Domingo Perón, reflected, in the field of housing, on the notion of the right to housing and a dramatic scaling up of social housing construction and flexible mortgage schemes (Constitución de la Nación Argentina, 1949; Ballent, 2005: 27-64).

Finally, it must be noted that these changing discourses and notions took place in an international context increasingly dominated by the United States and the emergence of panAmerican frameworks and policies. A crucial instance weaving together these dimensions with regard to housing was the First Pan-American Low-Cost Housing Congress (FPALCH), held in Buenos Aires in 1939 by initiative of the Pan-American Union. In his welcoming speech Argentine deputy Juan Félix Cafferata, promoter of the CNCB and president of the Congress, celebrated and explained the initiative:

Sin viviendas sanas no hay hogar, sin hogar no hay familia y sin familia no hay nación fuerte, próspera y grande [...] porque la promiscuidad, el hacinamiento, la inestabilidad, dispersan la familia, siembran en los espíritus ideas de rebelión, incitan al alcoholismo, depravan la juventud y corrompen la niñez [Without healthy houses there is no home, without home there is no family and without family there is no strong, prosperous and big nation [...] because promiscuity, overcrowding, instability, 
disperse the family, spread ideas of rebellion, instigate alcoholism, deprave youth and corrupt childhood] (Ministerio de Relaciones Exteriores y Culto, 1940: 50-51)

Furthermore, hygienic and well-organised housing did not only imply, for Cafferata, social rest and productivity, these in turn underpinning a strong nation state, but they also reflected the ideals of (Western) civilisation, itself conceived of as human development from (and contrasted with) nature:

No se concibe en la naturaleza [...] la conservación de las especies, sin un lugar adecuado donde nazcan y crezcan los nuevos seres. [...] Y el hombre, el rey de la creación, ¿Cómo es posible que se desenvuelva y alcance su plena integridad sin un hogar que lo ampare, lo defienda y que llene un mínimo de condiciones compatibles con su dignidad y su elevada jerarquía? "El individuo lanzado a la calle con su mujer y sus hijos, da al que lo contempla un espectáculo que clama al cielo como un crimen de lesa civilización" [The conservation of species is unconceivable in nature [...] without an adequate place for the new beings to be born and grow up [...] And man, king of creation, ¿How is it possible for him to develop and reach his full integrity without a home to shelter him, to protect him, and which fulfils a minimum of essential conditions compatible with his dignity and high hierarchy? "The individual thrown to the street with his wife and children offers, to those who observe him, a spectacle that cries out to heaven as a crime against civilisation"] (Ministerio de Relaciones Exteriores y Culto, 1940, p. 51; quotation marks in the original; italics are mine) 
The aforementioned positions towards social housing became particularly interesting in Argentina when applied to public policy on shantytowns a few decades later. In fact, the concerns then did not only include providing universal housing for a well-functioning society, but also dismantling the shantytowns, which were seen as hotbeds of vice and moral degradation, and as the reflection of residents' idleness and their engagement with political demagoguery. More specifically, the articulation of previous discourses, narratives and concerns regarding social housing into public policy addressed at shantytowns first took place in the context of a fiercely anti-Peronist dictatorship (1955-1958). These positions were condensed in the first shantytown eradication plan in Argentina, the Plan de Emergencia [Emergency Plan] (PE, 1956), and later re-casted in legislation and a second large-scale shantytown removal plan, the Plan de Erradicación de Villas y Barrios de Emergencia [Shantytowns and Emergency Neighbourhoods Eradication Plan] (PEVE, 1968).

The Plan de Emergencia read the shantytowns as not only a consequence of rapid urban growth, but also as the spatial outcome of residents' lack of initiative:

Venidos de zonas pobres, sin recursos y sin hábitos de trabajo, han sido atraídos por la gran ciudad en busca de mejoras económicas y de los halagos de la vida urbana. Pero el medio social de las Villas Miseria, en que se han agrupado por imperio de las circunstancias por falta de incentivo propio y de ayuda social, contribuye a agravar sus naturales tendencias y a convertir estas barriadas en focos permanentes de epidemias y de degradación moral: en su mayoría, sus habitantes requieren una acción urgente de readaptación social [Coming from poor areas, without resources and without working habits, [the villas' residents] have been attracted to the big city in search of economic betterments and the indulgences of urban life. But the social environment of the shantytowns, in which they have gathered by force of 
circumstance and for the lack of both incentives of their own and social help, contributes to worsening their natural tendencies and transforming these slums into permanent foci of epidemics and moral degradation: in their majority, their inhabitants require an urgent action of social re-adaptation] (Comisión Nacional de la Vivienda, 1956, p. 39)

The idea that the residents' cultural values were not suited to urban life, in fact, or that they were indolent, was reiterated throughout the Plan de Emergencia though not supported by empirical evidence. Quite the contrary, it was belied by the Plan's survey itself, which reported virtually full employment (99\%). The very fact of having migrated in search of economic betterments, in fact, and having created and maintained their own living environments with the resources available were in themselves a reflection of residents' proactivity, sacrifice and enthusiasm rather than idleness. The discourse of the PE did correspond, though, to reformist views about the social effects that living environments could have on the social structure, its stability and its productivity. In line with the latter, the PE proposed not only to evict residents from the shantytowns but also to re-house them in 'adaptation dwellings' where a fixed layout would lead them to get used to what the PE regarded as an urban, 'moral' lifestyle. The Plan considered that only nuclear families (father, mother and children) fitted this bill, and that any other living arrangements that the residents may have had to be eliminated. To this aim, it equipped the new houses with fixed concrete and steel furniture in order to make sure that the bedrooms were used for the people prescribed (steel frameworks were attached to the walls), and the dining room not used as a bedroom (concrete tables). The PE was halted less than a year after it was launched. Six neighbourhoods were, however, completed. 
The PEVE took a similar approach, though it added the idea of temporary housing: evicted shantytown residents would be first accommodated in temporary units, where they would experiment a 'cambio en las pautas habitacionales' [change in their dwelling patterns] (Ministerio de Bienestar Social, 1968, p. 08), to be later offered permanent houses. This process was to be overseen by social assistants. Thus, both space and social work would collaborate towards the PEVE civilising mission. The very idea of house as a transition thus implied, again, a normalisation:

El objetivo principal que deben cumplir estas localizaciones [the temporary houses] es, además de alojar mejor, servir como centros de adaptación para facilitar y acelerar el proceso de cambio de las familias [The main aim to be fulfiled by these temporary houses is, in addition to housing better, to serve as adaptation centres to facilitate and accelerate the families' process of change] (Ministerio de Bienestar Social, 1968, p. 10 ; italics mine)

The negative stereotypes about shantytown residents coined throughout the second half of the twentieth century are still prevailing, and have been further complicated by the idea of crime. To summarise, twentieth century stigmas towards the shantytown population focused on the rural origin of most migrants, which rendered them backwards or not ready for modern urban life in the eyes of the state and the urban middle classes, and also depicted them as indolent or vicious. With the focus of ethnic discrimination nowadays displaced from shantytown residents' rural to foreign backgrounds, they are currently stigmatised not only as indolent or vicious but also regarded with contempt if coming from neighbouring countries and blamed for what the middle classes refer to as insecurity and what the poor experience as everyday interpersonal violence (Auyero and Berti, 2015). 
The two fictional films Villa [Shantytown] (Ezio Massa, 2008) and Diagnóstico esperanza [Diagnosis Hope] (César González, 2013) question the preconceptions offered in discourses and plans about shantytown clearance and housing, though they do so in extremely different ways. Finalised in 2008, though not released in Argentina until 2013, Villa narrates the story of three young residents of the shantytown Villa 21 (Buenos Aires, Barracas) as they struggle to find a way to watch Argentina's first 2002 World Cup match in a colour TV (Fig. 1). In its depiction of the shantytown, the film reiterates tropes such as the value of community life, social ties and solidarity networks in shantytowns, and portrays a blurry boundary between inside and outside spaces whereby the main meeting place (the informal football pitch, or canchita) plays the role of almost a communal living room. These tropes are indeed different, and even contrary, as will be explained, to the stereotypes casted by the state. By the term 'tropes' I refer to, throughout this article, common understandings about shantytowns which appear reiterated historically across discourses and which, even though well intentioned, simultaneously risk simplifying excessively their depictions. Interpersonal violence is also present in Villa, although, as I will argue below, the film overall presents a celebration of shantytown life, questions the stigmatisation of its residents, and denounces social inequality.

Quite differently, Diagnóstico esperanza takes place in a PEVE complex of social housing, Barrio Carlos Gardel (Buenos Aires, Morón, El Palomar), which until recently received the denomination of 'shantytown' (both by the residents and generally) given the extreme degradation of its living environment (Fig. 1). Diagnóstico presents a snapshot of the lives of a selection of residents of Barrio Carlos Gardel while portraying thoroughly the spatial deterioration of common spaces. The lives narrated are not happily engaged in community endeavours, but rather crossed by anxiety and conflictive family ties. In addition, neither are the tropes of social or solidarity networks invoked: in fact, beyond a few relations 
of personal or family affection between individual characters, the film overall presents us with a society facing simultaneous crises of values, corruption, stigmatisation, and more especially material and symbolic inequality. In this way, Diagnóstico belies the eradication plans' expectation that the re-housing of shantytown residents would lead to families integrated into a 'nación fuerte, próspera y grande' [strong, prosperous and big nation] (Ministerio de Relaciones Exteriores y Culto, 1940, p. 50), not only because the families narrated do not comply with any of the standards that such plans prescribed but more especially because the idea of a grandiose nation itself has lost its meaning in the context of an unfair, corrupt, and marginalising society.

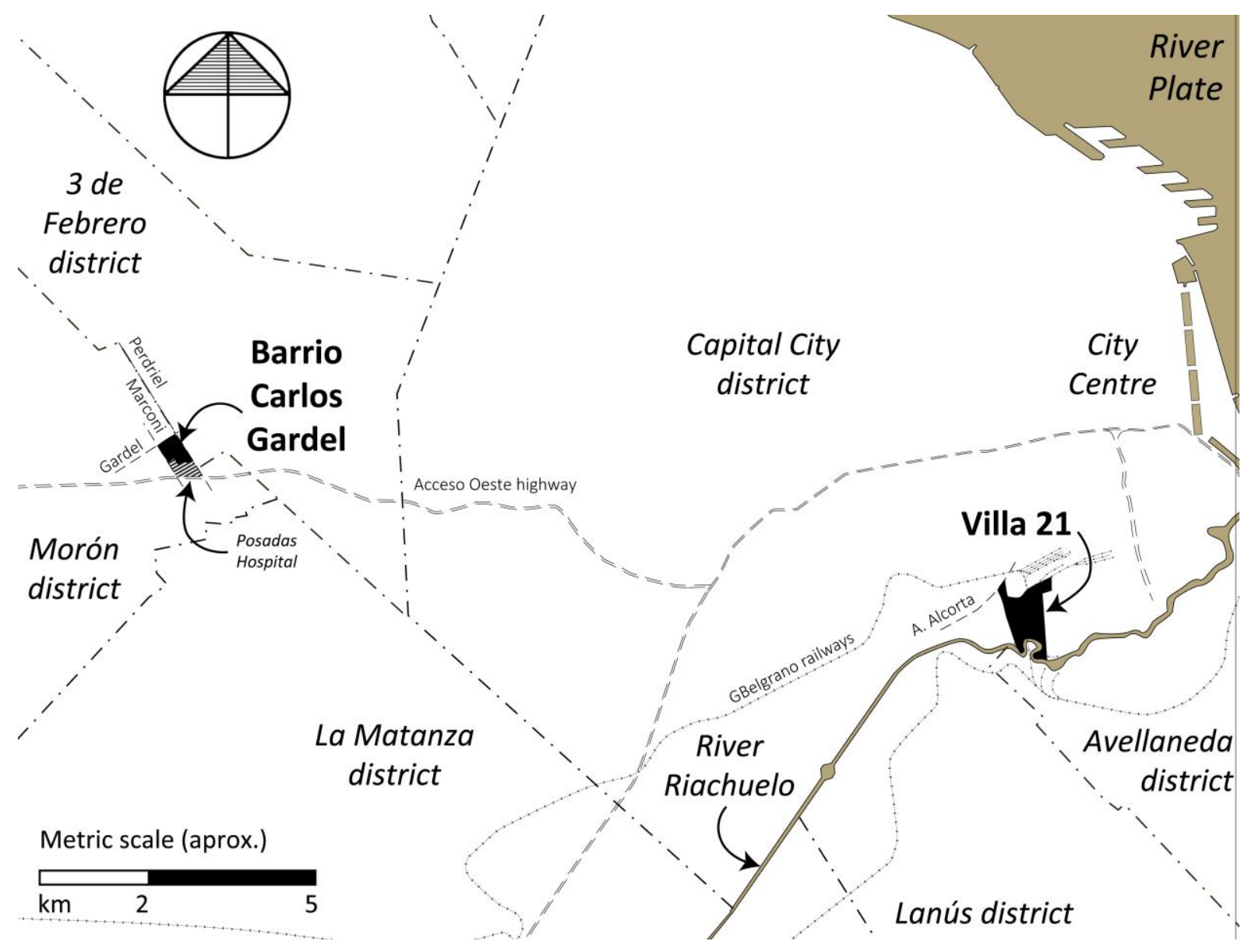

Fig. 1. Location of Villa 21 and Barrio Carlos Gardel within Buenos Aires. Source: author's drawing. 
Both films were conceived, to different degrees, with input from the residents of the spaces portrayed. However, while Villa was re-thought in conjunction with emerging actors and filmmakers from Villa 21, but ultimately directed by Ezio Massa, Diagnóstico esperanza was itself conceived and made by a film director from Barrio Carlos Gardel, Carlos González. It is possible to trace this difference in the plots, in some features, and in the general approaches of both films. Massa started to form the idea for Villa when, in the midst of the 2002 crisis, he passed by a central shantytown, Villa 31 (Buenos Aires, Retiro), and was struck by the poverty observed: 'Lo primero que sentía es “¡esta gente siempre estuvo en crisis!”... Y, “¿cómo estarán viviendo el mundial?”" [The first thing I felt was "these people have always been in crisis!"... And, "how may they be experiencing the World Cup?"] (VILLA - Making Off, 2008, 1'32). It was a in a similar way that journalist Bernardo Verbitsky, in the 1950s, had been attracted to Villa Maldonado (Ciudadela, destroyed by fire in 1955), which inspired his landmark novel Villa Miseria también es América (Verbitsky, 1957; Ulanovsky, 1997). Massa engaged in collaboration with an NGO linked to Villa 21, SOS Discriminación, to realise his idea for Villa, and with residents who were already starting to engage in filmmaking, amongst them Nidia and Julio Zarza (Massa, 2013). The script was partially adapted by its actors (almost all of them non-professional actors from the shantytown itself, trained for the film): 'fueron los chicos los que me dieron la lección de que ellos no hablaban como estaba en el guión y empecé a rearmar los diálogos guiados por los propios chicos. Son diálogos de ellos' [It was the kids who taught me the lesson that they did not speak as was written in the script, and I started re-arranging the dialogues guided by the kids themselves. The scripted dialogues are theirs] (Russo, 2013). Massa has also underlined that he fulfilled the commitment to include absolutely in the film, in some capacity (for example, some as extras), all the residents who attended the first casting meeting. 
Despite these exciting engagements with Villa 21 residents, Villa was ultimately directed by Massa, and it stands as a realisation of his original concept. It is not only the fact that they were inspired by an incidental contact with urban poverty that Villa and Villa Miseria también es América have in common: there is also the underlying agenda of contesting contemporaneous tropes of stigmatisation of shantytown residents. In the 1950s, these were, as explained before, the ones reflected by the Plan de Emergencia: the accusation of residents being indolent, uneducated, and 'immoral' (Comisión Nacional de la Vivienda, 1956). In the 2000s, the main stigmatising tropes are those which relate and blame the shantytowns for crime and insecurity. Violence, when existing, strikes on the residents themselves stronger than on any member of the middle classes, and this is what Villa attempts to portray (VILLA - Making Off, 2008, 13'22; for a comparable argument, though not in a shantytown, see Auyero and Berti, 2015). For example, the casting videos included in the making of (of non-selected actors) reflect an explicit intention, either by the actors/residents, the director, or both, of fighting back stigmatisation through underlining the residents' hardworking and non-criminal nature (VILLA - Making Off, 2008, 4'30). However, in its confrontation of stigmatising tropes, Villa partially reiterates a series of long-standing tropes itself: community life, solidarity, or spaces of encounter such as the canchita. To this regard the film positions its point of view from outside the shantytown universe: it can be read more as the deployment of a series of positive preconceptions about the shantytowns, themselves in discussion with a series of negative preconceptions (all of these coined by middle classes and ruling élites), than as the engagement with something new, or with topics emerging from Villa 21 itself and not previously imagined by the middle classes. The narration of the voice over underlines this approach: along the first $30^{\prime}$ of the film, the shantytown is introduced to an audience which is assumed to be new to it through explanations and shots of shantytown spaces. 
Having said the above, and despite it partially relying on tropes, it must be noted that the questioning of middle-class discourses about shantytowns and criminality in Villa is not uni-dimensional. There are three main ways in which Villa pursues its endeavour. First, as has just been mentioned, we have a reiteration of positive tropes: the shantytown is seen and presented as a space of solidarity, of community life, where residents are able to work together in their pursuit of a common goal. These aspects were first proposed by Verbitsky in Villa Miseria también es América but can also be found in the discourse of the Left in Argentina during the 1950s and 1960s (for example, in Communist newspapers such as La Hora or Nuestra Palabra), in publications produced by shantytown residents (such as La Voz de las Villas), or in the way in which the topic has been approached by the social sciences (Ziccardi, 1977; Cuenya et al., 1984; Gúber, 1991).

The celebration of community life is structured, in Villa, around the space of the canchita de San Blas, crucial for the depiction of the shantytown: 'En la villa hay un lugar donde todos nos juntamos. Donde está todo bien. Ese lugar es la canchita de San Blas, frente a la capilla' [In the shantytown there's a space where we all get together. Where everything is OK. That space is the San Blas canchita, in front of the parish] (Massa, 2008, 9'34; first voice over) (Fig. 2). Since the 1970s canchitas, or informal football pitches, have been read by the social sciences as a public space of particular importance in shantytowns because they played a key role for the formation of shantytown identities and the meeting of residents (Ziccardi, 1977). In the case of the canchita de San Blas, its importance in relation to the practice of community football is further reinforced by its relation with religious practice: the pitch is located not only in front of a Catholic parish but also sided by a sanctuary to the Gauchito Gil, a folk saint or figure of popular devotion in Argentina (Salvador, 2016; Massidda, 2014). 


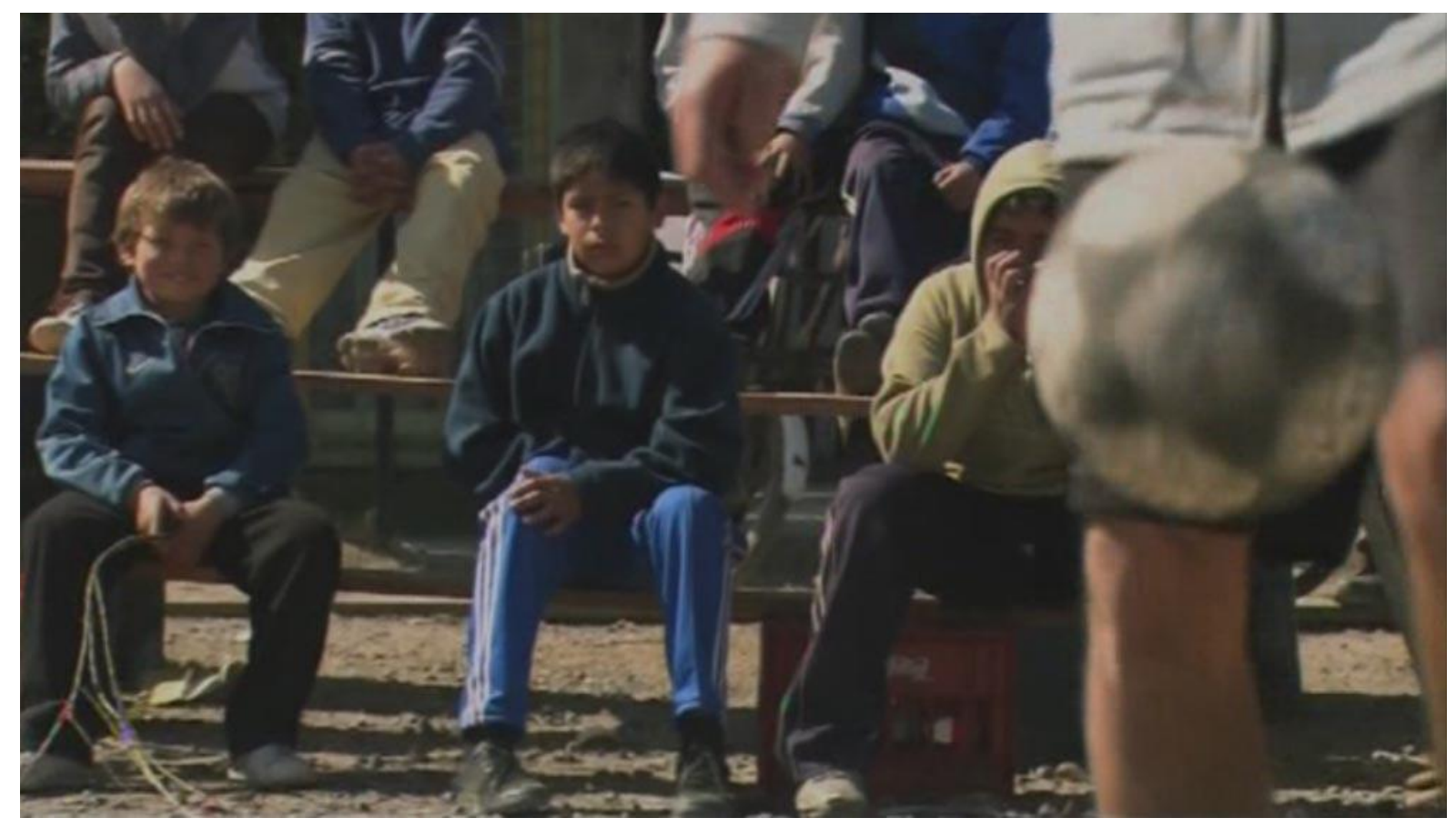

Fig. 2. Pick-up football and informal community gather in the Canchita de San Blas, Villa 21. Source: Villa, Ezio Massa.

The celebration of community life is intertwined in Villa with an emphasis on the cheerful everyday atmosphere of Villa 21 . Throughout the first 30 ' of the film, the audience is invited to engage with snapshots of various spaces across Villa 21, all of them public, which add to the canchita: over background percussion reminiscent of candombe (in this case a theme based on 'Chiruda Stone', by La Chilinga) we see a deployment of bright colours in the corridors of the shantytown as residents go about doing their business, kids (all male) play football, and people joke back and forth with their neighbours while walking (Fig. 3). The voices of football commentators relating the preparations and expectations which surround the start of the World Cup are layered over the percussion music creating a feeling of everyday excitement. The pedestrian perspectives of these shots contrast with the aerial views offered together with the voice over (de Certeau, 1984), though both contribute to the articulation of the same narrative. Furthermore, the film makes consistent use of humour. At night, the three film protagonists' comments reiterate the ideas of solidarity and friendship: ‘(Freddy) Nos tenemo’ entre nosotros... ni siquiera tu vieja te quiere (Lupin) Che Cuzquito no 
te sobra una frazada?' [(Freddy) We have one another... not even you mum loves you (Lupin) Hey Cuzquito, don't you have a spare blanket?] (Massa, 2008, 9').

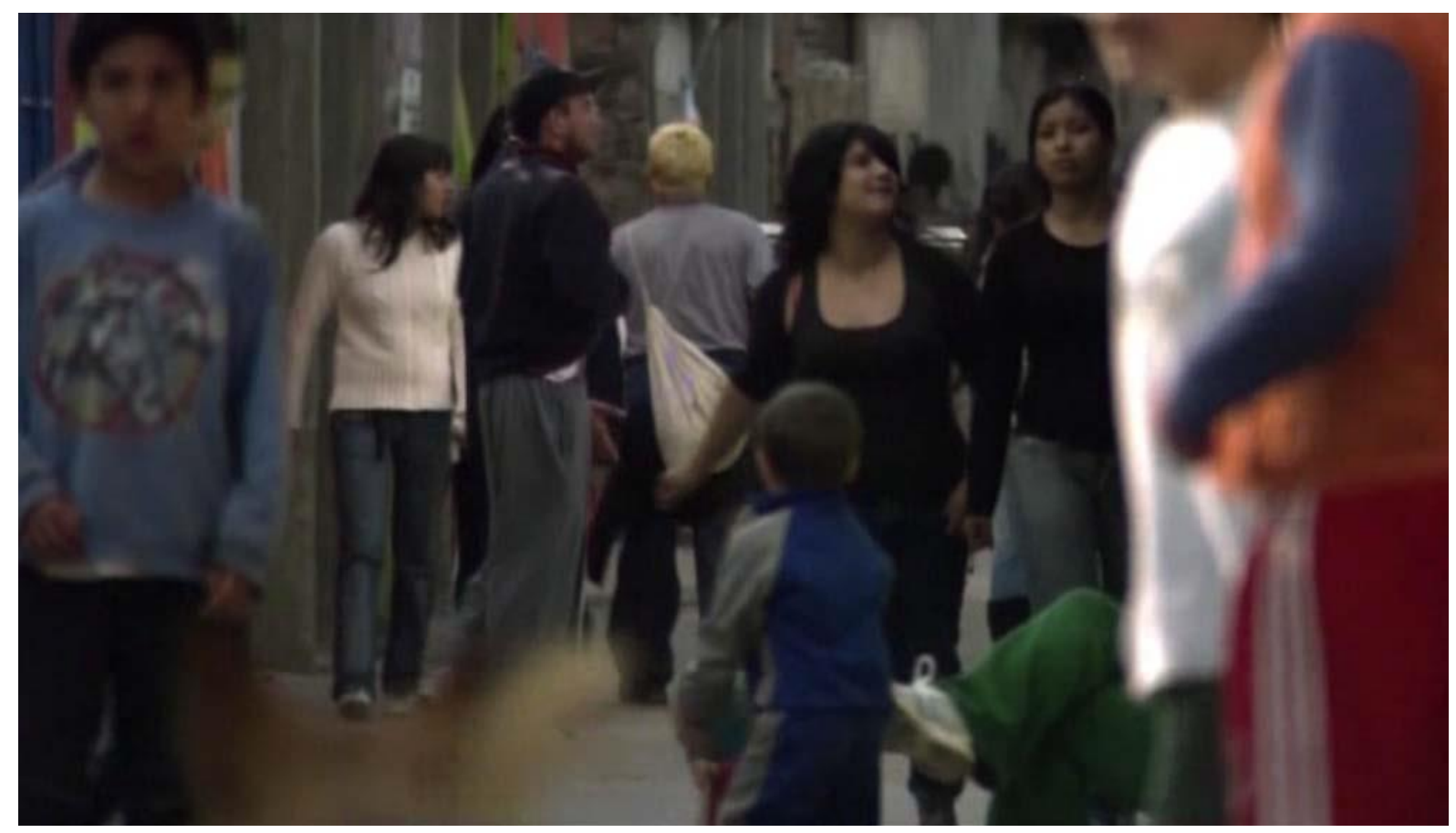

Fig. 3. Everyday business in Villa 21 corridors. Source: Villa, Ezio Massa, 2008.

Second, the film is intended as a denunciation of marginalisation, which becomes evident as the latter is scattered through numerous brief statements. The opening scene is particularly clear in this regard: the background commentary of the opening ceremony of the World Cup, which digresses about the importance of football for young people and insists that youth and sport have 'shaken hands' in the Cup, turns into hypocrisy insofar as the three protagonists are struggling to squeeze a glimpse of it through a pizza shop window. Furthermore, this becomes particularly acute when these are chased out by the shop owner while a policeman patrols the area. In addition, the film's denunciation is indirectly articulated in the figure of a non-shantytown lady who refuses to be scared of the residents, and also at moments through Freddy's own voice: 
¿Sabés dónde tendríamos que estar nosotros? ¡Allá afuera, loco, no mendigando una imagen loco! [...] ¿Qué somos nosotros, loco? [...] ¡esto es una porquería, loco, parece una caja de pan loco! iiyo no mendigo nada acá en mi rancho, loco, yo no mendigo nada!! [D'you know where we should be? Out there, mate, not begging for an image, mate! [...] What are we, man? [...] This is a piece of junk, man, it looks like a bread box man! I don't beg to anyone here in my shack, man, I don't beg anyone!!] (Massa, 2008, 57’42).

Third, and in relation to violence, the idea of gangsters is detached from those presented as the shantytown residents proper. This becomes particularly evident through the brief narrative of the second voice over, which is in fact a playful intertwining of the voices of Jonathan Rodríguez and Julio Zarza (actors for Cuzco and Freddy respectively). This places the protagonists as those who introduce the audience to the shantytown. The three protagonists of the film are actually quite far from gangsters, their main interest being to actually see the match. In order to do so, for example, Lupín trespasses into an electronics shop, and manages to see most of the match in a concert of TV screens of different sizes. He is the only one who will end up arrested, though for scarcely a few minutes: while the police officials are distracted watching the match themselves he escapes again. Cuzco breaks into the flat of the old lady who was trying to help him, but soon forgets that his role is meant to be threatening as he lets himself be carried away by the match. Freddy becomes a failed gangster: he is the only of the three who employs physical violence, but is not as interested in committing crime as he is in seeking revenge from the shantytown arm dealers and the pizza shop owner (in addition to, of course, watching Argentina-Nigeria).

The questioning of stigmas is the way in which Villa seeks to interrogate spatial determinism, i.e., contesting the idea that the material problems of the shantytowns space (shortage of piped water and sewage, precariousness of constructions, floods) both determine 
and reflect a human nature of its inhabitants as indolent, 'immoral' (as per the PE), or even criminal. Villa presents a reading of shantytowns whereby what matters in space is the way in which it fosters community life and where its inhabitants, though exposed to poverty and crime, work to move on and improve their lives. The exceptions to this are, clearly, Freddy and the arm dealers. Freddy's character, however, reinforces rather than questions this reading of the shantytown, since it places the blame for poverty on marginalisation and stigma as social processes and not on the shantytown as a spatial environment.

Diagnóstico esperanza, differently, does not explicitly focus on questioning stigmas but engages with the lives of a selection of residents from Barrio Carlos Gardel as they go about a few days in their lives. In this way, however, it seriously questions not only the deterministic idea sustained by shantytown eradication plans (such as the PEVE, under which the Barrio was designed) according to which modern housing design would promote and strengthen the Western institution of the nuclear family, but also that idea of family itself. To start with, the notion of motherhood, crucial to the idea of family, is unstabilised in Diagnóstico as it is crossed by anxiety, desperation, and atmospheres of domestic violence. Of the three mothers featured or mentioned, one has abandoned her child (Ledesma's mum), the other is worried about both her children's relation to crime (the older has just come out of prison, the younger is on his way to following in his footsteps), and the third (Naza) is fraught with despair and frustration in her attempt to support her family on her own through drug dealing, which leads her to a consistent practice of verbal abuse. The views about motherhood proclaimed close to the start by one of the secondary characters are not contested by the narrative of the film hereinafter and thus they remain as a central portrayal of intimate, and later and domestic, dynamics: 'Me gusta ese instinto animal que tienen de querer todo el tiempo que les den, que les den [...] “¡Llename, llename, llename, llename!” [...] Después ni 
se hacen cargo; después se olvidan que tienen un nene adentro nueve meses' ['I like that animal instinct they have of wanting to get sex, to get sex all the time [...] "fill me up, fill me up, fill me up, fill me up!” [...] Afterwards they don't take responsibility; afterwards they forget that they have a child inside for nine months'] (González, 2013; 22'50). Quite the contrary, the figure of abortion is presented as an unattainable desire by Naza, in fact one of the film's protagonists: 'Te juro que, si hubiera tenido un peso de más, ¿sabés cómo aborto un par de guachos? 'que mirá lo que es mi vida, boludo, llena de pibes, de pibes, 'toy re podrida...' ['I can swear to you that, had I had one peso more, d'you know how I'd had aborted a few kids? 'cause look what my life has become, mate, full of kids, kids, I'm fed up'] (González, 2013; 36’40).

Furthermore, it is Naza's home in particular that embodies some of the most interesting domestic processes in Diagnóstico. As the site of a small cottage industry, one related to the processing and sale of drugs, it is continuously crossed and interpenetrated by the outside to the inside in a way that belies bell hooks' representation of the homes of the marginalised as a site of resistance (Fig. 4). hooks analyses the world of care and protection created by black mothers throughout African-Americans history as the way they found to contest a white and extremely hostile exterior (hooks, 1991: 46-47). In their homes, the absence of whiteness meant absence of hostility and reflected an explicit intention of not allowing the racial tensions of the prevailing social system to penetrate the space of the home, preventing them from affecting their children. In Naza's home, differently, spaces are crossed back and forth continuously. Not only the dining room is the main working space in the house, as drugs processing takes place simultaneously and intertwined with meals, but selling is done through the back window and buyers are a constant presence in domestic life. Policemen, too, come to collect and negotiate their bribes in that same dining room, while both the dining room and the patio frame the conversations around a planned larger crime 
(the breaking into and burglary of cash from a middle-class home) that gets ultimately frustrated.

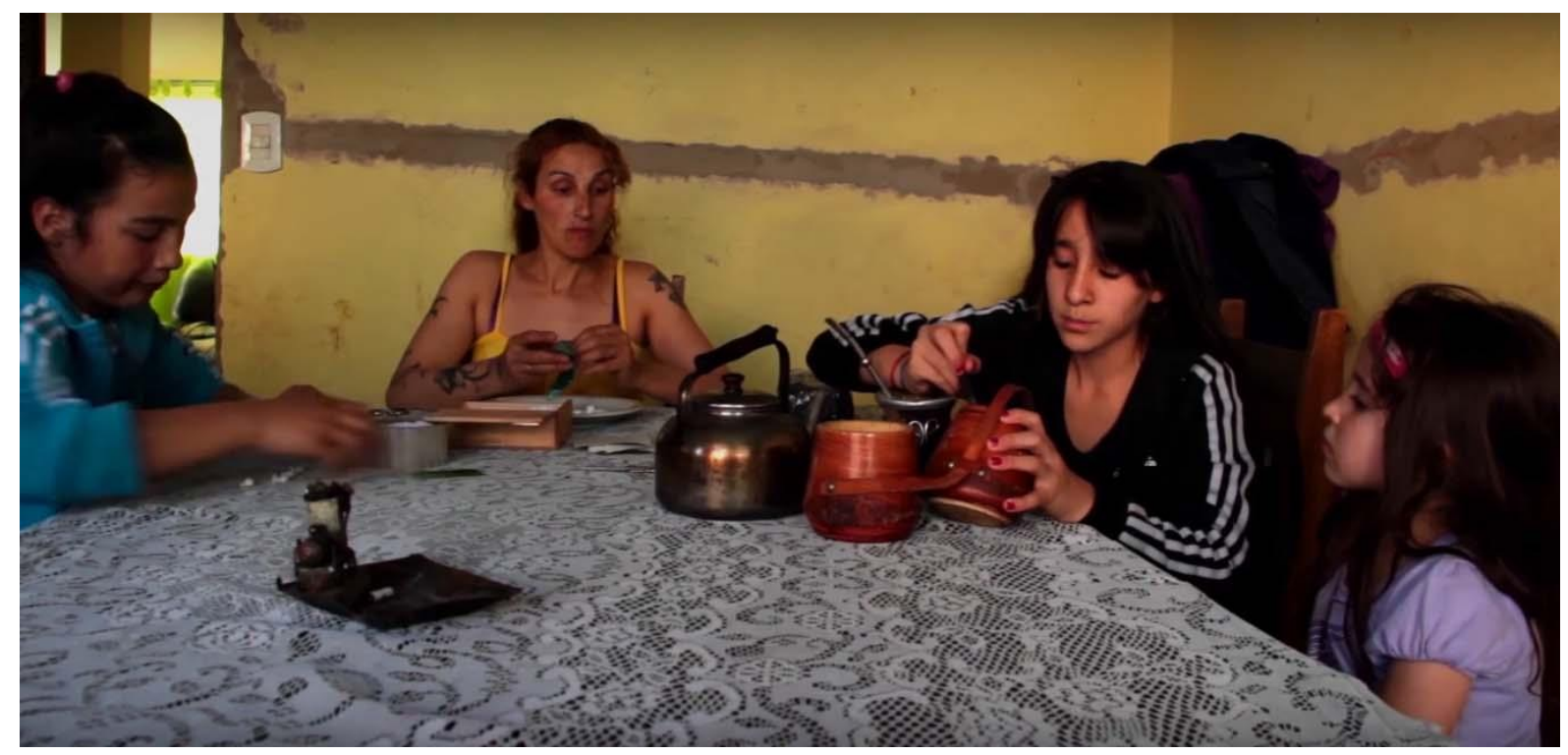

Fig. 4. Domestic space at Naza's home. Source: Diagnóstico Esperanza, César González, 2013.

The schematic visions about home, society and nation held by eradication plans are therefore not only belied by the tensions narrated in Diagnóstico esperanza, but they also feel alien in the context of the world of affections and conflicts that it narrates. Designed in 1970 by the Argentine architectural office STAFF (led by Jorge Goldemberg, Ángela Teresa Bielus and Olga Wainstein-Krasuk), the complex originally called Conjunto Morón won the competition for the PEVE housing schemes numbered 11, 12 and 13. It consisted of a series of four-storey monoblocks located within the streets Marconi, Carlos Gardel, and Perdriel (current República), north of the Posadas Hospital, in the district of Morón (Bielus et al., 1971). The Argentine Spanish term monoblocks refers to high-density, mid-rise buildings where one of the horizontal dimensions predominates over the vertical, resulting on long and flat concrete blocks. Later on, the complex became known by the more specific name Carlos Gardel, following the street that structured the main entrance into the monoblocks area. Also as part 
of the PEVE initiative a large number of temporary housing units were set up in the area, leading to a rapidly deteriorating environment (Rametta and Canali, 2006; Costa, 2009) (Fig. 5).

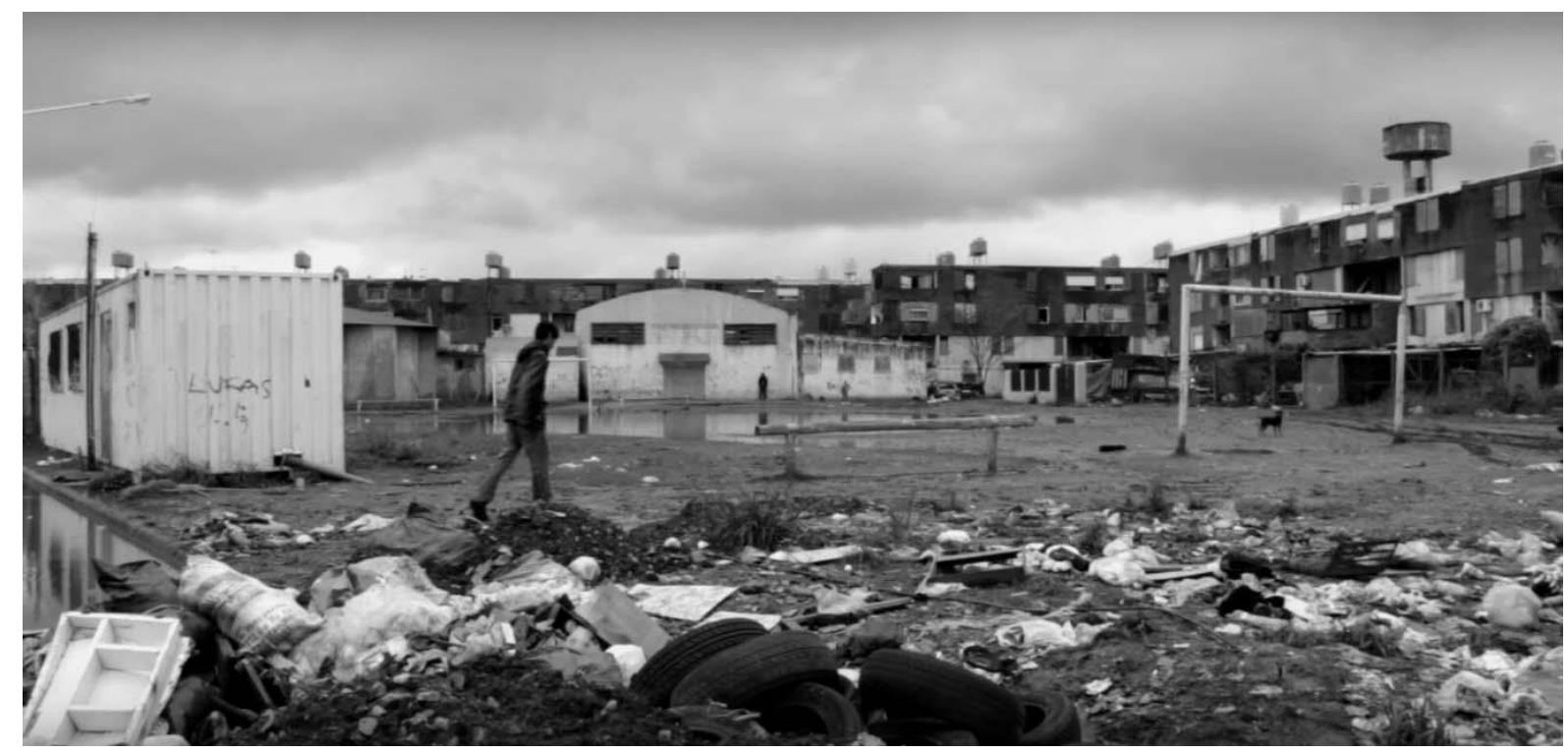

Fig. 5. Barrio Carlos Gardel. Source: Diagnóstico Esperanza, César González, 2013.

The spatial degradation of the whole complex led to it being colloquially referred to as a shantytown, and it is in fact called villa by César González and some of the critics who have written about the film (González, 2013, 85’00; Franc, 2013). A full discussion of the blurriness of the boundary between the denominations, conceptualisations and spatial realities of shantytowns and social housing estates in Buenos Aires unfortunately exceeds the scope of the present article. Indeed, it must be noted that very often social housing complexes have been built to re-house evicted shantytown residents, afterwards not properly maintained and re-labelled as shantytowns by either the State, the residents, the public or all of these. When listed as shantytowns by the state, and despite being under its management, social housing complexes have often in turn spiralled into a process of informalisation (Massidda, 2011, 2016). With productive and labour structures untouched, residents have been as deprived in one as in the other environment, though liable to accommodation instalments when housed by 
the state. However, what this article specifically highlights in relation to Diagnóstico is the way in which the space was originally shaped by architectural and state conceptions.

In their description of the project, the Carlos Gardel architects reiterate state conceptions of shantytown residents as maladjusted to urban life and 'con tendencia al aislamiento' ['with a tendency to self-isolation'] (Bielus et al., 1971). Thus, even though they do not proclaim a specific definition of home and family as the FPALCH or the PE had done, they do not challenge it, implicitly sharing their narrative and their approach. STAFF approach was framed by a more general conceptualisation of collective housing by Argentine architects whereby the housing unit was thought of as a cell which, through repetition, would scale up to become a tissue (Summa, 1967; Aliata, 2004). Interestingly, architectural critic Marina Waisman presents a new version of spatial determinism when introducing a retrospective journal issue on the work of STAFF: 'una urbanización efectiva puede dar al migrante acceso al grado de conciencia necesario para advertir las contradicciones de la sociedad global, convirtiéndose en fuente de posiciones reinvindicatorias' ['an effective urbanisation can offer the migrant access to a degree of consciousness necessary to identify the contradictions of global society, becoming a source of reclaiming positions'] (Waisman, 1973, p. 15). Unfortunately, such process whereby modern housing would lead to social mobilisation is not explained further or developed by Waisman though concrete examples.

The conflicted versions of home presented in Diagnóstico esperanza are contrasted in the film with a society not only focused on consumerism and material values but also one where affective relations are alienated. This, in turn, renders ideas of the family such as those proclaimed by the FPALCH, and together with it the conceptual construction of a nation-state, meaningless. One of the key characters outside Carlos Gardel, in fact, the shopkeeper, offers information and access to his brother in law's house to Ledesma, a corrupt policeman, not 
only expecting to obtain a material reward for it (a share of the robbery profits) but also out of resentment and envy. The same shopkeeper enthusiastically joins a rally in the city centre, likely to refer to the anti-government protests held under the administration of Cristina Fernández de Kirchner and known as 8N ('Después del 8N', 2012). The abstraction of the narrative sustained in this rally, which is depicted invoking national symbols such as the flag, the national anthem, the country's name or the term 'democracy', turns into emptiness when juxtaposed and shown in contrast to the misery and desperation experienced by the Gardel characters. Another character, the sock seller, breaks into and robs a house mainly to replace his trainers: while the trainers are shown as broken in a previous shot, the choice and process of buying them arguably implies consumerism as much as it implies need. Furthermore, when preparing for a robbery, two of the main characters plan their enjoyment of the profits:

Yo me voy a ir, también, amigo, me voy a ir de vacaciones, me vo'a comprar mi nave, me vo'a comprar un par de llantas... [...] al baile, al puterío... y despué' en la semana salir a comer... Por eso, hay que hacer vida de bacán, amigo, ¿qué te pensás? [...] ¿que los chetos nomás pueden bacanear? [I'm also gonna go, mate, I'm gonna go on holidays, I'm gonna buy my car, I'm gonna buy a few trainers... [...] go to the club, the brothel... and then during the week go out for dinner... That's it, we must live an indulgent life, friend, how come not? [...] or only the posh kids can live indulgently?’ (González, 2013; 79’58)

Ideas of consumerism, society and nation, are therefore deeply intertwined in Diagnóstico's reframing of the ideas of home and family. In fact, revealing the tensions between the ideas of families and consumerism as sold by the media, on the one hand, and as they are attainable by Carlos Gardel residents, on the other, has been crucial to González's biography and work: 'Y te ponía triste también ver la televisión, y el modelo de familia que te vende la televisión 
hasta el día de hoy, ¿no? [...] Hay un montón de familias en los barrios, ¿no? donde vos ves que la madre es la hermanita de 11 años' ['And you'd get sad watching TV, and the family model that TV tries to sell to you even today, no? [...] there are a lot of families in the shantytowns/neighbourhoods, aren't they? where you see that the mum is the little 11-old sister'] (González, 2014, 5’16).

Final thoughts

The representations of the reciprocal influence between human practices and the environment discussed throughout this article reflect the productive tension that exists between the terms 'house' and 'home', 'domestic space', and 'housing'. Itself difficult to define, the home has been seen as 'the seat of domestic life and interests', '[t]he place where one lives or was brought up, with reference to the feelings of belonging, comfort, etc., associated with it', or simply '[t]he domestic setting' ("home, n.1 and adj.," n.d.). The house, in turn, is identified more clearly with the shelter offered by a material construction ("house, n.1 and int.," n.d.). However, for being such, a 'house' needs to be sheltering a specific type of human practice: the hotel, the asylum, the office are not 'houses' in the same way that they are not 'homes' (Douglas, 2006). In this way, house and home are implicated in a close relation whereby both shape the meaning of the other without this relationship ever being neither transparent nor straightforward.

The re-framing of twentieth-century ideas of house, housing and home in Villa and Diagnóstico esperanza does not close down the discussions about the relation between space and human practice. On the contrary, it potentiates them with further notions of housing, homes, domesticity, and also society. Diagnóstico esperanza is particularly acute in its depiction of environmental decay and its engagements with the complexity of related human, 
spatial and material tensions. Both films contest stigmatising discourses and grand rhetoric about nation building, and they equally present a different view regarding shantytowns than more widely promoted works like Elefante blanco (Pablo Trapero, 2012), which does not dismantle such narratives. In this sense, and despite their differences and the complexity of the topics narrated, Villa and more especially Diagnóstico can be read as potentially first steps within an emergent counter-hegemonic production about shantytowns. The involvement of residents makes a crucial difference to this regard. In relation to this, thus, and even though arguably pessimistic in their denunciation of social inequality and also their critique of the unsuitability of pre-existing notions of home, both films however open up new conversations on the ideals and practices that surround the house, and by doing so they embody a new route to interrogate the relation between human practice and the domestic environment.

\section{$\underline{\text { Referenced works }}$}

Aliata, Fernando (2004) 'Sistemas (arquitectura de)', in Diccionario de arquitectura en la Argentina: estilos, obras, biografías, instituciones, ciudades, eds. Fernando Aliata and Jorge Francisco Liernur (Buenos Aires: Clarín Arquitectura/AGEA), 57-60.

Auyero, Javier, and María Fernanda Berti (2015) In Harm's Way: The Dynamics of Urban Violence (Princeton : Princeton University Press).

Ballent, Anahi (2005) Las huellas de la política: vivienda, ciudad, peronismo en Buenos Aires, 1943-1955 (Buenos Aires: Universidad Nacional de Quilmes/Prometeo).

Bielus, Teresa, Olga Wainstein-Krasuk, and Jorge Goldemberg (1971) 'Conjunto Morón, Haedo, Buenos Aires'. Summa 36: 33-36.

Certeau, Michel de (1984) The Practice of Everyday Life (Berkeley: University of California Press). 
Comisión Nacional de la Vivienda (1956) Plan de Emergencia: Informe elevado al Poder Ejecutivo Nacional (Buenos Aires: Ministerio de Trabajo y Previsión).

Constitución de la Nación Argentina (1949) (Buenos Aires: Congreso de la Nación).

Costa, María Ignacia (2009) 'Gubernamentalidad y condiciones de vida. El caso del complejo habitacional Carlos Gardel - Presidente Sarmiento (Morón, Provincia de Buenos Aires)'. Margen 54.

Cuenya, Beatriz, Ernesto Pastrana, and Oscar Yujnovsky (1984) De la villa miseria al barrio autoconstruido: cuatro experiencias organizadas de producción del hábitat popular (Buenos Aires: Centro de Estudios Urbanos y Regionales).

'Después del 8N' (2012) Página 12, 12 November 2012.

Douglas, Mary (2006) 'The Idea of Home: A Kind of Space', in Housing and Dwelling: Perspectives on Modern Domestic Architecture, ed. Barbara Miller Lane (New York: Routledge), 61-81.

Ernste, Huib, and Christopher Philo (2009) 'Determinism/Environmental Determinism', in International Encyclopedia of Human Geography, eds. Nigel Thrift and Rob Kitchin (Oxford: Elsevier), 102-110.

Franc, Luis (2013) 'A propósito de Diagnóstico esperanza: una máquina de guerra'. Hacerse la crítica: escritura crítica de cine.

González, César (2013) Diagnóstico esperanza.

(2014) interviewed by Julio Leiva, televised in La máquina de escribir voces, November 2014, https://www.youtube.com/watch?v=Ee3rj9jHY-0. Accessed 20 March 2017.

Gorelik, Adrián (1998) La grilla y el parque: espacio público y cultura urbana en Buenos Aires, 1887-1936 (Buenos Aires: Universidad Nacional de Quilmes). 
Gúber, Rosana (1991) 'Villeros o cuando querer no es poder', in Barrio sí, villa también: dos estudios de antropología urbana sobre producción ideológica de la vida cotidiana, eds. Rosana Gúber and Ariel Gravano (Buenos Aires: Centro Editor de América Latina) , 1162.

'Home, n.1 and adj.' (2017) OED Online (Oxford University Press) Accessed 9 March 2017. http://www.oed.com/view/Entry/87869?rskey=7NwOuK\&result=1\#eid.

Hooks, Bell (1991) Yearning: Race, Gender and Cultural Politics (London: Turnaround).

'House, n.1 and int.' (2017) OED Online. (Oxford University Press) Accessed 9 March 2017. http://www.oed.com/view/Entry/88886?rskey=HvaQlf\&result=1\#eid.

Lecuona, Diego Eugenio (2001) 'Conceptos políticos y sociales sobre el problema de la vivienda en Argentina a mediados del siglo XX'. Revista INVI: Boletín del Instituto de la Vivienda 16/42: 7-59.

Massa, Ezio (2008) Villa.

(2013) interviewed by Adriana Laura Massidda, 9 August 2013.

Massidda, Adriana Laura (2011) 'The Unsettling Nature of Barrio Rivadavia 0-1-2 in Buenos Aires: Transitions of Formality/Informality. Paper read at the conference Informality: Re-Viewing Latin American Cities , University of Cambridge, Cambridge, 17-19 February.

(2014) 'Villa (2013)', in World Film Locations. Buenos Aires, eds. Michael Pigott and Santiago Oyarzabal (Bristol: Intellect books), 122-23.

(2016) 'Shantytowns and the Modern City: Examining Urban Poverty in SouthWestern Buenos Aires (1958-1967)’ PhD diss., University of Cambridge.

Ministerio de Bienestar Social (1968) Plan de Erradicación de las Villas de Emergencia de la Capital Federal y el Gran Buenos Aires: Primer programa - erradicación y alojamiento transitorio. 
Ministerio de Relaciones Exteriores y Culto (1940) Primer Congreso Panamericano de La Vivienda Popular: Actas y trabajos. 2 vols. (Buenos Aires: Talleres gráficos del Ministerio de Obras Públicas).

Peabody Group (2017) 'Peabody: Our Heritage', http://www.peabody.org.uk/about-us/whowe-are/our-heritage. Accessed 20 March 2017.

Rametta, Mariela, and Mariela Canali (2006) 'De la "erradicación de villas” a la construcción de un barrio: una breve historia de los barrios Presidente Sarmiento y Carlos Gardel'. Revista de Historia Bonaerense 31: 62-71.

Rigotti, Ana María (1991) 'El reformismo oligárquico y las casas para obreros'. Estudios Sociales 1/2: 5-27.

Russo, Juan Pablo (2013) 'Ezio Massa: "Hoy las películas están una semana en cartel y van al muere", escribiendocine, March 8.

Salvador, Mauro Daniel (2016) 'Gauchito Gil, entre la adoración y la justicia divina: Un acercamiento al mito religioso popular desde la comunicación'. Question 1/50: 428-40.

Summa (1967) 10, full issue.

'The Peabody Trust and the Poor' (1885) The Saturday Review, 21 February 1885.

Ulanovsky, Carlos (1997) Paren las rotativas: una historia de grandes diarios, revistas y periodistas argentinos. (Buenos Aires: Espasa).

Verbitsky, Bernardo (1957) Villa Miseria también es América (Buenos Aires: G. Kraft).

VILLA - Making Off (2008) (Buenos Aires: Paula Flics/Malevo Producciones).

https://www.youtube.com/watch?v=WQijGUaI72I.

Waisman, Marina (1973) 'Hacer es la consigna'. Summa 64-65: 13-18.

Ziccardi, Alicia (1977) 'Políticas de vivienda y movimientos urbanos: El caso de Buenos Aires (1963-1973)’ Masters diss., Centro de Estudios Urbanos y Regionales, Instituto Torcuato di Tella. 
